\title{
Population structure of turbinid gastropods on wave-exposed subtidal reefs: effects of density, body size and algae on grazing behaviour
}

\author{
Thomas Wernberg ${ }^{1,2, *}$, Melissa White ${ }^{2}$, Mathew A. Vanderklift ${ }^{1,3}$ \\ ${ }^{1}$ Centre for Marine Ecosystems Research, Edith Cowan University, Joondalup, 6027 Western Australia, Australia \\ ${ }^{2}$ School of Plant Biology, University of Western Australia, Crawley, 6009 Western Australia, Australia \\ ${ }^{3}$ CSIRO Marine and Atmospheric Research, Private Bag 5, Wembley, 6913 Western Australia, Australia
}

\begin{abstract}
Knowledge of the population structure and feeding capabilities of herbivores is critical to evaluate their influence on energy flow and community structure in their habitats. We tested for patterns in abundance (24 reefs) and size (12 reefs) of turbinid gastropods across 4 locations spanning $>6^{\circ}$ latitude $(\sim 1000 \mathrm{~km})$ in Western Australia, and we tested the effect of density (1 to 5 individuals) and size (38.8 to $747.1 \mathrm{~g}$ wet wt) of Turbo torquatus on consumption of macroalgae with different thallus structure (Functional Groups 3 to 5). Turbinid gastropods were found at all locations (up to 2.4 ind. $\mathrm{m}^{-2}$ ); $82.4 \%$ of all individuals were T. torquatus. One location (Marmion, Perth) had considerably higher abundances than all other locations. Populations of T. torquatus at the 2 southern locations had a broad range of sizes (9 to $119 \mathrm{~mm}$ total shell length [TSL]), although 1 location was dominated by small, and the other, by large, individuals. In contrast, both northern locations were strongly dominated by 1 size class (40 to $60 \mathrm{~mm}$ TSL). T. torquatus consumed Ulva lactuca, Hypnea valentiae, Hennedya crispa and juvenile Ecklonia radiata at rates of 150 to $450 \mathrm{mg}$ blotted fresh weight $\mathrm{d}^{-1}$, depending on density of gastropods and species of algae. There was a positive relationship between the rate of consumption and size of $T$. torquatus when fed $U$. lactuca and $H$. valentiae. The present study has produced 3 main insights: (1) densities of turbinids on offshore, wave-exposed, subtidal reefs are similar to those in other coastal habitats; (2) patterns of abundances and sizes are consistent with broad-scale processes, such as ocean climate, fishing pressure and eutrophication; and (3) $T$. torquatus can consume a variety of macroalgae at rates that suggest it has the potential to exert topdown control of macroalgae, although low densities of gastropods preclude strong effects.
\end{abstract}

KEY WORDS: Turbinid gastropods · Turbo torquatus $\cdot$ Broad-scale patterns · Population structure · Offshore subtidal reefs $\cdot$ Grazing rates $\cdot$ Kelp beds

Resale or republication not permitted without written consent of the publisher

\section{INTRODUCTION}

The impact of grazing at a location depends on the abundance, size and behaviour of its herbivores. Herbivorous gastropods are common in most coastal habitats, and grazing gastropods often determine the distribution of macroalgae on intertidal rocks (e.g. Jenkins et al. 2005). Gastropods can also influence the distribution of algae on subtidal reefs (Ayling 1981, Lotze \& Worm 2000), although they rarely have as spectacular effects as those of sea urchins, which can completely denude reefs of all erect vegetation (Hagen 1995, Hill et al. 2003).

Turbinid gastropods are widely distributed on both intertidal and subtidal reefs (e.g. Worthington \& Fairweather 1989, Ompi 1994, Foster \& Hodgson 2000, Vanderklift \& Kendrick 2004). Members of the genus Turbo are often conspicuous herbivores because they can attain large sizes and locally high densities. In Australia, for example, Turbo jourdani can reach an impressive size of $>20 \mathrm{~cm}$ height (Wilson 1993) and T. undulatus can be found in massive aggregations 
(intertidal: $>100 \mathrm{~m}^{-2}$, Worthington \& Fairweather 1989; subtidal: $>20 \mathrm{~m}^{-2}$, Edgar et al. 2004). The abundance and the size distribution of turbinid gastropods on intertidal reefs change along environmental gradients associated with elevation (Worthington \& Fairweather 1989, Bruton et al. 1991), and similar patterns may be found along the depth gradient on shallow subtidal reefs (Clarkson \& Shepherd 1985). There have been relatively few studies of turbinids on subtidal compared to intertidal reefs, and almost all have focused on nearshore, shallow reefs $(<8 \mathrm{~m})$, or reefs of low to intermediate wave exposure (e.g. Clarkson \& Shepherd 1985, Vanderklift \& Kendrick 2004). Consequently, although deeper $(>10 \mathrm{~m})$ and more waveexposed offshore reefs comprise substantial areas, little is known about the abundance and distribution of turbinids in these habitats. Similarly, climate conditions can affect the recruitment, post-settlement performance and population structure of gastropods (e.g. Zacherl et al. 2003, Gilman 2006), but it is not well understood if and how the population structure of turbinids changes towards their warmer range limits.

Marine herbivorous gastropods are mostly generalist feeders that are not associated with specific food sources (Steneck \& Watling 1982). Nevertheless, preference hierarchies, where certain algae are selectively consumed or avoided, still exist (e.g. Chan \& Huang 1998, Lotze \& Worm 2000, Davis et al. 2005), and this selectivity can affect habitat structure by suppressing some species of algae, and so advancing other species (Lotze \& Worm 2000). Selection for, or avoidance of, certain food items may be associated with their nutritional quality (Cronin et al. 2002, Kraufvelin et al. 2006) or the presence of chemical or structural deterrents (Davis et al. 2005, Paul et al. 2006). Palatability can also influence selection of food. Depending on size and structure of the feeding apparatus of the herbivore, algae with complex morphologies can be difficult to handle and manipulate, and tough epidermal cells can be difficult to sever and penetrate (Steneck \& Watling 1982). Such structural resistance to grazing is among the ecological properties considered in the functional group classification of algae, where higher functional groups are assumed to have greater resistance to herbivores (Steneck \& Watling 1982). Nevertheless, the ability of Turbo species to consume common algae of different thallus structure appears poorly resolved. On the basis of radula structure, Steneck \& Watling (1982) classified the archaeogastropods, including Turbo spp., as predominantly feeding on microalgae and finely structured filamentous algae, yet, guts from several different species of Turbo usually contain a broad variety of fleshy and calcareous macroalgae (Clarkson \& Shepherd 1985, Worthington \& Fairweather 1989, Chan \& Huang 1998, Foster \&
Hodgson 1998). This suggests that macroalgae constitute an important part of the diet of Turbo species and, therefore, that Turbo grazing may influence the distribution and abundance of macroalgae, depending on their feeding rates.

Quantitative knowledge of abundance, distribution and feeding capabilities is critical to evaluate any potential influence of herbivores on energy flow and community structure in their habitats. Filling the current knowledge gaps will provide insights into the effect of ocean climate on turbinids on temperate reefs, and it will enhance the understanding of community dynamics and potential control of algae on reefs that contribute significant trophic subsidies to adjacent habitats (e.g. Wernberg et al. 2006). This study aimed to quantify the abundance and distribution of turbinid gastropods on wave-exposed reefs dominated by the small kelp Ecklonia radiata, in order to test for spatial patterns along $>6^{\circ}$ of latitude $(\sim 1000 \mathrm{~km})$ and to test the ability of the most abundant species, Turbo torquatus, to feed on common macroalgae with different thallus structures. This included testing whether gastropod density and size influence grazing rates. In addition, key biometric relationships were extracted in order to derive regression models to enable future non-destructive field assessment of gastropod biomass.

\section{MATERIALS AND METHODS}

Surveys. The geographic distribution and abundance of turbinid gastropods was quantified during November and December 2005 by surveying 6 waveexposed reefs within each of 4 locations in Western Australia (Fig. 1). Locations were separated by 300 to $400 \mathrm{~km}$ coastline $\left(\sim 2^{\circ}\right.$ latitude). Reefs within each location were separated by $>1 \mathrm{~km}$, all were 10 to $12 \mathrm{~m}$ deep, and all were dominated by a low canopy of the small kelp Ecklonia radiata (e.g. Wernberg et al. 2003). Turbinid gastropods were counted within 5 replicate $1 \times 5 \mathrm{~m}$ belt transects separated by 5 to $10 \mathrm{~m}$ (cf. Vanderklift \& Kendrick 2004). Size-frequency distributions of Turbo torquatus were obtained between October and November 2006 from a subset of 3 reefs within each location. A diver searched each reef carefully, collecting all individuals encountered. The aim was to collect $\sim 25$ individuals from each reef, but densities were so low at some reefs that even extensive searching yielded fewer individuals. Total shell length (TSL) was measured in situ with vernier callipers, as the distance from the protoconch to the bottom of the outer lip (Wilson 1993).

Grazing experiments. The ability of Turbo torquatus to consume macroalgae of different thallus structure (Table 1) was tested in a series of laboratory experi- 


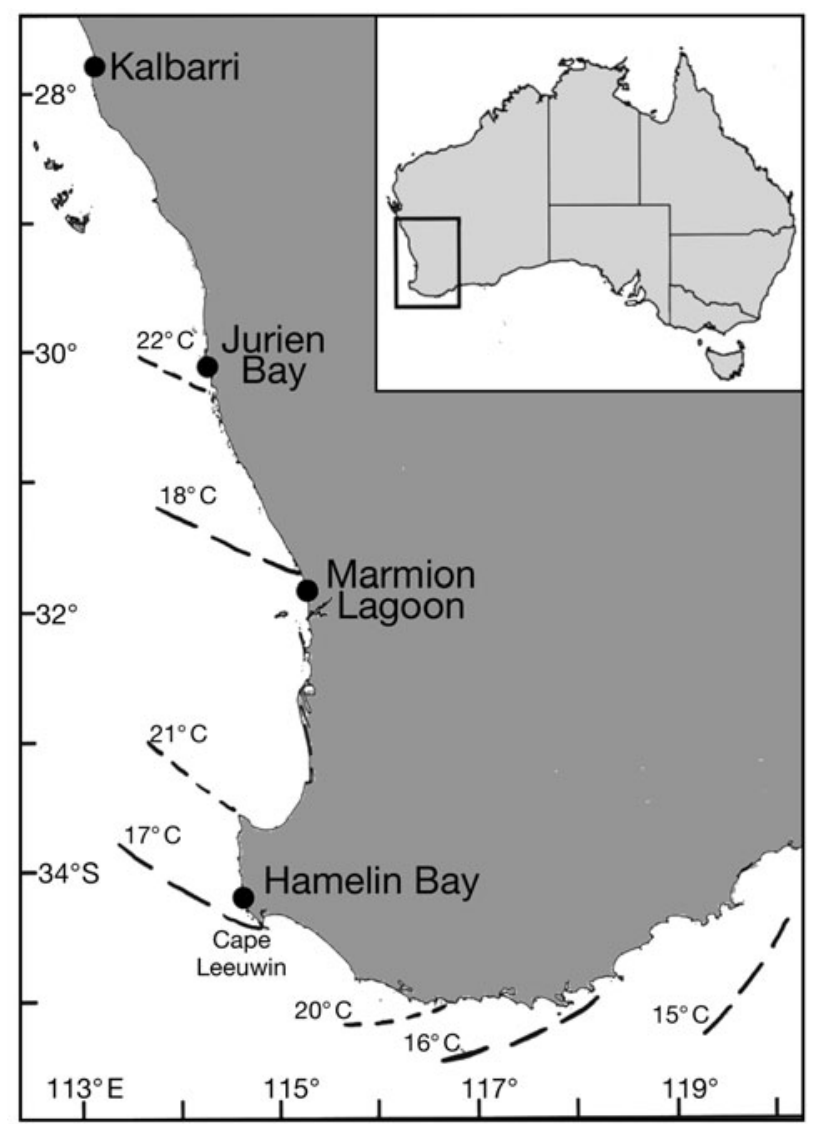

Fig. 1. Map of southwestern Australia showing the 4 locations where turbinid gastropods were surveyed $(\bullet)$, and typical summer (short dash) and winter (long dash) surface isotherms (after Pearce 1991)

ments. Gastropods and algae were collected from subtidal reefs around Perth (Western Australia) between January and April 2006. All gastropods were replaced every 2 to $3 \mathrm{wk}$, and the algae, every week. Newly collected specimens were always allowed to acclimatise to laboratory conditions for at least $24 \mathrm{~h}$ before being used in experiments. While not in use in experiments, all gastropods were kept together in a large aquarium where they had access to a mixed assemblage of macroalgae, to avoid pre-conditioning them to a particular food source. For each experiment, gastropods and algae were transferred to experimental units (15.4 1 aquaria), and left to graze for 2 to $5 \mathrm{~d}$ depending on the rate of biomass removal for each species of alga. All aquaria were aerated and maintained in a temperature-controlled aquarium room $\left(22^{\circ} \mathrm{C} \approx\right.$ temperature in situ) under full light from fluorescent aquarium lamps (12:12 h light:dark cycle). Faecal material was removed from all aquaria daily by siphoning, at which time $\sim 25 \%$ of the water was replaced. Biomass of algae (blotted fresh weight, FW) was measured at the beginning and at the end of each experiment, and consumption rates were calculated as change in biomass per day.

For experiments testing for effects of density of Turbo torquatus on the 4 species of macroalgae (Table 1), 5 replicate aquaria were stocked with $0,1,2$, or 5 gastropods and 0.5 to $1.5 \mathrm{~g} \mathrm{FW}$ algae. These stocking densities mimicked the range of commonly observed aggregations of Turbo spp. in areas of comparable size to the experimental aquaria (T. Wernberg pers. obs.). The gastropods used in these feeding assays ranged in size from 33.8 to $123.5 \mathrm{~g} \mathrm{WW}$ (wet weight), with a mean $( \pm \mathrm{SE})$ of $54.8 \pm 1.9 \mathrm{~g} \mathrm{WW}(\mathrm{n}=$ 160 ), and there were no differences in the mean size of gastropods used in the feeding assays for any of the 4 algae $\left(F_{3,56}=1.08, \mathrm{p}=0.37\right)$. The algae used are all common on the southwest coast of Western Australia (Wernberg et al. 2003 and references therein).

The effect of gastropod body size on grazing rates was tested for 2 species of algae, which the previous experiments had shown to be readily consumed by medium-sized Turbo torquatus. One gastropod, ranging in size from 38.8 to $747.1 \mathrm{~g} \mathrm{WW}$, was used in each experimental unit.

Biometric relationships. Relationships between wet weight (WW), operculum diameter (OD), total shell length (TSL) and ash-free dry weight (AFDW) were determined for Turbo torquatus. WW was measured after removing excess water by gently shaking each gastropod, operculum facing down. AFDW was calcu-

Table 1. Species of macroalgae used in the experiments to determine grazing rates of different densities and sizes of gastropods Turbo torquatus. Characterisation of thallus structure is based on Womersley (1984, 1987, 1994). FG: functional group in decreasing rank order of predicted palatability (Steneck \& Watling 1982)

\begin{tabular}{|lllc|}
\hline Species & Division & Thallus structure & FG \\
\hline Ulva lactuca & Chlorophyta & Foliose, 2 cells thick, simple sheet & 3 \\
Hypnea valentiae & Rhodophyta & Foliose, corticated (cortex 1-3 cells thick), cylindrical & 4 \\
Hennedya crispa & Rhodophyta & Cartilaginous, corticated (cortex 3-5 cells thick), complanate & 4.5 \\
Ecklonia radiata ${ }^{\text {a }}$ & Phaeophyta & Leathery macrophyte, corticated (cortex many cells thick w. meristoderm), planar & 5 \\
a5 to $10 \mathrm{~cm}$ well-developed juveniles. These are sometimes classified in FG 4. To retain the rank order of palatability \\
implied by the thallus anatomy, we have not done so here
\end{tabular}


lated by subtracting shell and ash weight from the dry weight, where dry weight was measured after drying at $60^{\circ} \mathrm{C}$ until constant weight (usually $3 \mathrm{~d}$ ), and ash and shell weight was measured after incineration in a muffle furnace at $500^{\circ} \mathrm{C}$ for $24 \mathrm{~h}$.

Statistical analyses. Differences in abundances of gastropods among locations and reefs within locations were tested with a random-factor, nested ANOVA. One-way ANOVA was used to test if size-frequency distributions of Turbo torquatus were different among locations; the Canberra metric (Clarke \& Warwick 2001) was used to calculate the absolute distance (sum of distances at each size increment) between cumulative relative frequency distributions for all pairs of reefs, testing whether within-location distances were smaller than among-location distances. For each feeding assay, a separate 1-way fixed-factor ANOVA was used to test the effect of density of $T$. torquatus on consumption of algae. Product moment correlation was used to assess the relationship between algal functional group and total consumption of each type of algae, summed across all density treatments containing T. torquatus. All ANOVAs were done using the program PERMANOVA, calculating $p$-values from 9999 permutations of residuals under the reduced model (Anderson 2005). The permutational approach was desirable because the data contained many zeros (particularly the survey data) and were highly nonnormal even after transformation. Linear regression was used to test the effect of gastropod size on consumption rates and to fit biometric relationships. Where appropriate, data were $\ln (x)$-transformed prior to regression in order to obtain expected linear relationships.

\section{RESULTS}

\section{Surveys}

Four species of turbinid gastropods were recorded in transects during the survey: Turbo torquatus, $T$. intercostalis, Australium squamifera and A. tentorium. Two additional species, T. jourdani (Marmion, Jurien Bay) and T. gruneri (Hamelin Bay, Marmion), were seen on some reefs, but never within the transects. Moreover, with the exception of 5 abalone Haliotis laevigata encountered in Hamelin Bay, these turbinids were the only large $(>3 \mathrm{~cm})$ herbivorous gastropods encountered. $T$. torquatus accounted for the vast majority of all turbinids $(82.4 \%$ of all individuals), and variation in this species determined the overall patterns of distribution of turbinid gastropods (Fig. 2). T. intercostalis (seen at the 3 northernmost locations) and the 2 species of Australium were too sparse and occurred too infrequently to reveal any spatial patterns of distribution other than relative rarity. The spatial distribution of turbinid gastropods was characterised by large variation at several spatial scales (Table 2), but most variation was found among locations 100s of kilometres apart (40\%) and transects within reefs $10 \mathrm{~s}$ of metres apart (39\%). Turbinid gastropods were more abundant in Marmion Lagoon than anywhere else (post hoc pairwise comparisons: Marmion > Hamelin Bay = Jurien Bay = Kalbarri). Marmion was also the only location where turbinids were found on all reefs. The mean abundance of turbinid gastropods ranged from 0 to 5.6 ind. transect ${ }^{-1}$ (1.1 ind. $\left.\mathrm{m}^{-2}\right)$, although most sites where turbinids were found had $<1.6$ ind. transect ${ }^{-1}$ $\left(0.32\right.$ ind $\left.\mathrm{m}^{-2}\right)$. The highest density recorded in a single transect was $12\left(2.4\right.$ ind. $\mathrm{m}^{-2} ; 11 \mathrm{~T}$. torquatus, 1 A. squamifera).

A broad range of sizes of Turbo torquatus were found at both of the southern locations (9 to $119 \mathrm{~mm}$

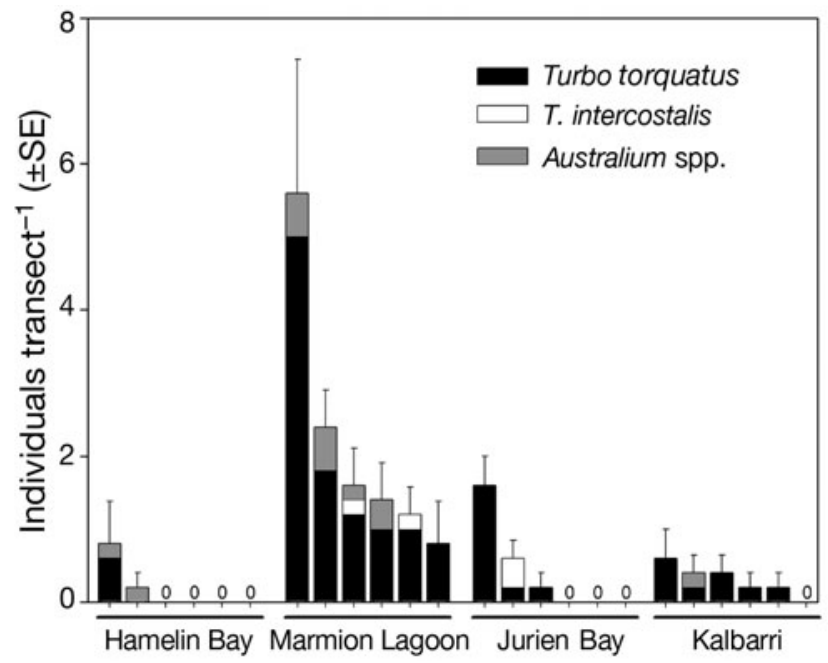

Fig. 2. Abundance of turbinid gastropods at 6 sites within each of 4 locations along the south-western coastline of Western Australia. Error bars are SE ( $\mathrm{n}=5$ transects) for total abundance of turbinids

Table 2. Results of analysis of variance testing for differences in abundances of turbinid gastropods. The p-values were calculated from 9999 permutations of the residuals (Anderson 2005). Data were $\ln (x+1)$ transformed; Cochran's $C=0.1230$, $p>0.05$. The contribution to variance was calculated as the percent contribution of variance components to total variance

\begin{tabular}{|lcccrc|}
\hline $\begin{array}{l}\text { Source of } \\
\text { variation }\end{array}$ & df & MS & $F$ & $\mathrm{p}$ (perm) & $\begin{array}{c}\text { Contribution } \\
\text { to variance }\end{array}$ \\
\hline Location & 3 & 4.529 & 9.37 & 0.001 & $40 \%$ \\
Site(Location) & 20 & 0.483 & 3.59 & $<0.001$ & $21 \%$ \\
Residual & 96 & 0.135 & & & $39 \%$ \\
\hline
\end{tabular}


TSL), but, while the populations in Hamelin Bay were skewed towards large individuals (85\% >50 mm TSL), the populations in Marmion Lagoon were skewed towards small individuals (61\% <50 mm TSL) (Fig. 3). In contrast, populations at both of the 2 northern locations, Jurien Bay and Kalbarri, were strongly dominated by a single intermediate size class (72\% of individuals between 40 and $60 \mathrm{~mm}$ ). The size-frequency distributions were similar among reefs within all locations (Fig. 3), and, consequently, there was a significant difference among locations in the size-frequency distributions of $T$. torquatus $\left[F_{3,8}=7.69, \mathrm{p}(\right.$ perm $)=$ 0.0003; Fig. 3]. Post hoc pair-wise comparisons indicated that size distributions in Hamelin Bay and Marmion were different to all other locations [p(perm) $<0.022]$, while size distributions in Jurien and Kalbarri were not different to each other $[\mathrm{p}($ perm $)=0.549]$ $(\mathrm{HAM} \neq \mathrm{MAR} \neq \mathrm{JUR}=\mathrm{KAL})$.

\section{Grazing experiments}

There was a significant consumption of all species of macroalgae offered to Turbo torquatus during the feeding assays (Table 3, Fig. 4), but the rate of consumption at different densities of $T$. torquatus varied among algae. There was virtually no change in biomass for any of the algae in aquaria without $T$. torquatus, indicating very little autogenic change took place over the duration of each feeding assay. Consumption rates by single individuals were not detectably different to the treatment with no gastropods for any of the food sources, although there was an indication of consumption of Ulva lactuca by single individuals (Fig. 4). Consumption by pairs of individuals was significantly higher than in the no-gastropod treatment for all algal species, except Ecklonia radiata, where no consumption was detected at this density. The consumption rate

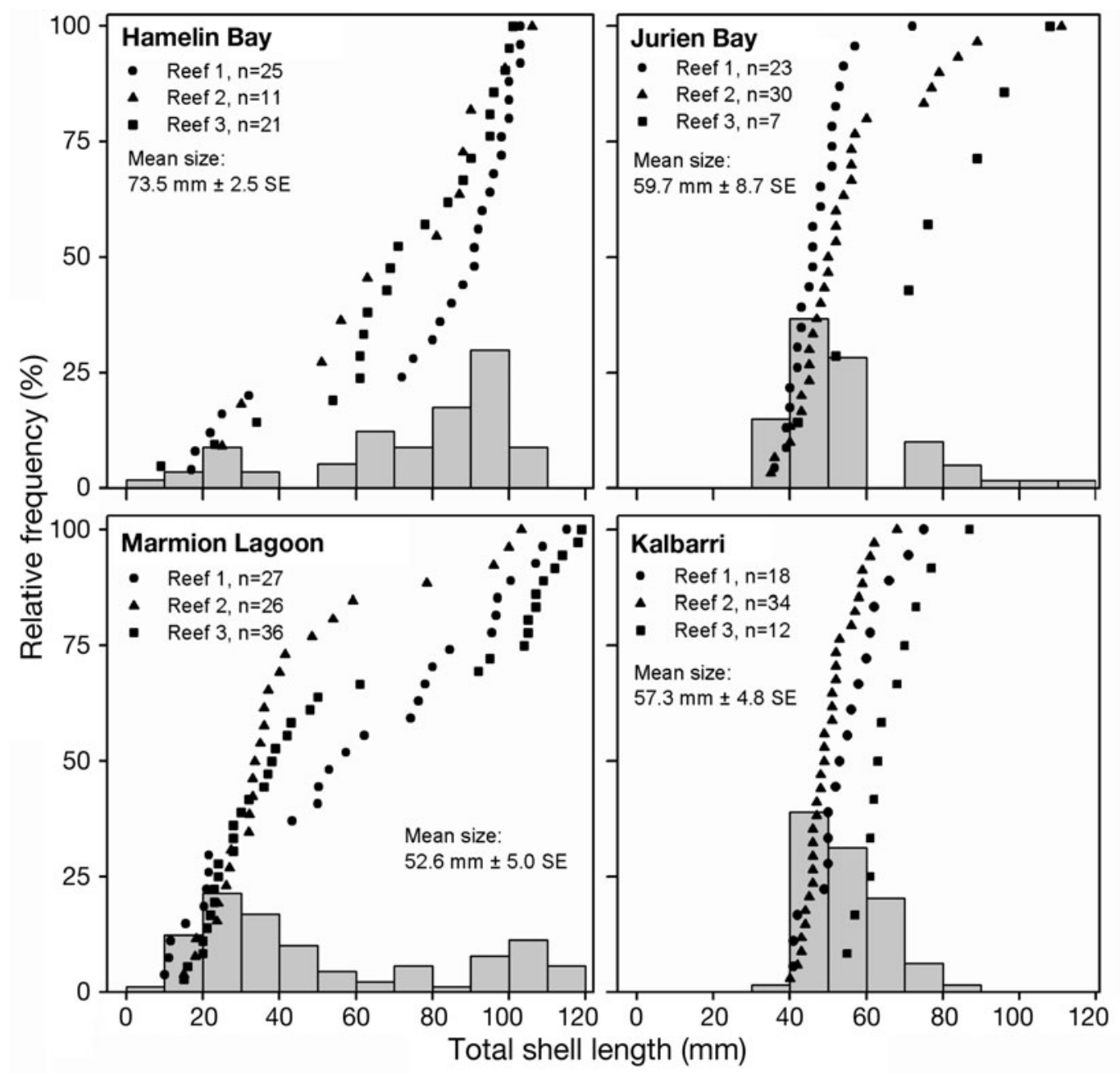

Fig. 3. Turbo torquatus. Cumulative size-frequency distributions at individual reefs $(\bullet, \mathbf{\Delta}, \mathbf{\square})$ and size-frequency histograms (10 mm size classes) pooled across reefs, within each of 4 locations along the south-western coastline of Western Australia. Mean size is the average of 3 reefs 
for U. lactuca ( 300 mg $\left.\mathrm{FW} \mathrm{d} \mathrm{d}^{-1}\right)$ was approximately twice that for Hypnea valentiae and Hennedya crispa ( 150 mg FW d $\left.{ }^{-1}\right)$. Consumption rates did not differ between 2 and 5 ind. aquarium ${ }^{-1}$ for U. lactuca, $H$. valentiae, or $H$. crispa. With 5 ind. aquarium ${ }^{-1}, E$. radiata was consumed at a rate of $\sim 150 \mathrm{mg} \mathrm{FW} \mathrm{d}^{-1}$. U. lactuca was the only species of alga where a progressive increase in consumption was evident with increasing density of gastropods. There was a strong negative correlation between algal functional group and total

Table 3. Turbo torquatus. Results of analysis of variance testing for effects of density of gastropods on consumption rates of different species of macroalgae. The p-values were calculated from 9999 permutations of the residuals (Anderson 2005)

\begin{tabular}{|lrcc|}
\hline Macroalga & MS & $F$ & p(perm) \\
\hline Ulva lactuca & 166036.7 & 5.15 & 0.013 \\
Hypnea valentiae & 17767.7 & 5.14 & 0.015 \\
Hennedya crispa & 16823.7 & 5.38 & 0.013 \\
Ecklonia radiata $^{\mathrm{a}}$ & 7.2 & 6.30 & 0.001 \\
a Data were $\ln (x+24)$ transformed; \\
$0.4318<$ Cochran's $C<0.6206, p>0.05$ \\
\hline
\end{tabular}

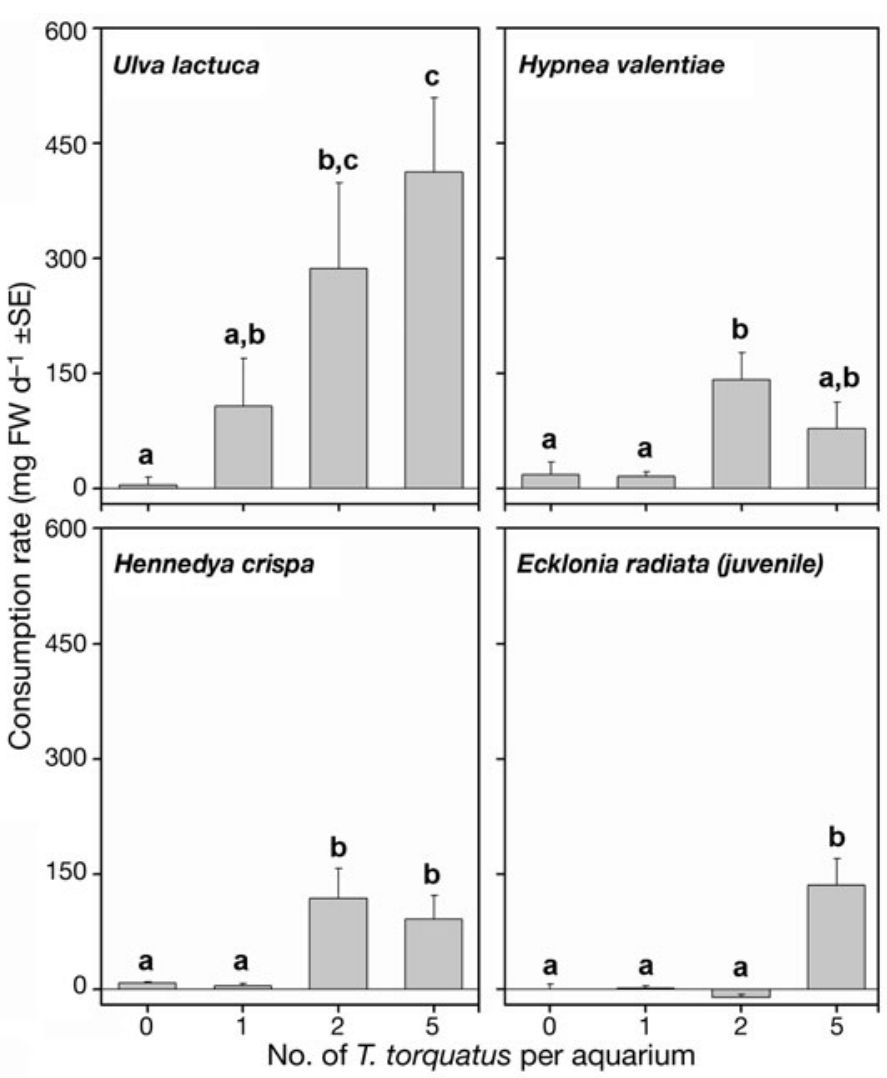

Fig. 4. Turbo torquatus. Consumption rates of macroalgae by different densities of gastropods. Error bars are SE ( $n=5$ aquaria), and letters above each bar indicate results of post hoc pair-wise comparisons ( $p>0.05$ for shared letters) consumption of algae, across the 4 feeding assays ( $\mathrm{r}=$ $-0.94, \mathrm{n}=4)$.

There was a significant $(\mathrm{p}<0.01)$ positive relationship between the size of Turbo torquatus and consumption rates of Ulva lactuca and Hypnea valentiae (Fig. 5). However, the slope of the regression line for $U$. lactuca (slope $=0.45$ ) was $>4$ times smaller than that of $H$. valentiae (slope $=2.01$ ), suggesting a difference in the size dependency of consumption of the 2 algal species; there were no differences in consumption rates when fed to large individuals, but smaller individuals ate $U$. lactuca much more readily than they $\operatorname{did} H$. valentiae.

\section{Biometry}

The shell fraction (shell + operculum, \pm SE) accounted for $65.4 \pm 0.4 \%(n=28)$ of total gastropod wet weight, and there was only a weakly negative relationship between gastropod size and shell fraction $(\mathrm{r}=-0.24, \mathrm{p}=$ $0.21, \mathrm{n}=28$ ). The relationships between Turbo torquatus WW, OD and TSL, and AFDW were highly significant and had high regression coefficients (Table 4). The best predictor of AFDW was TSL, closely followed by WW.

\section{DISCUSSION}

Our survey found differences in abundance and size structure among locations separated by 100s of kilometres, with abundances dominated by Turbo torquatus. In laboratory experiments, $T$. torquatus consumed a range of common macroalgae, but at rates that varied

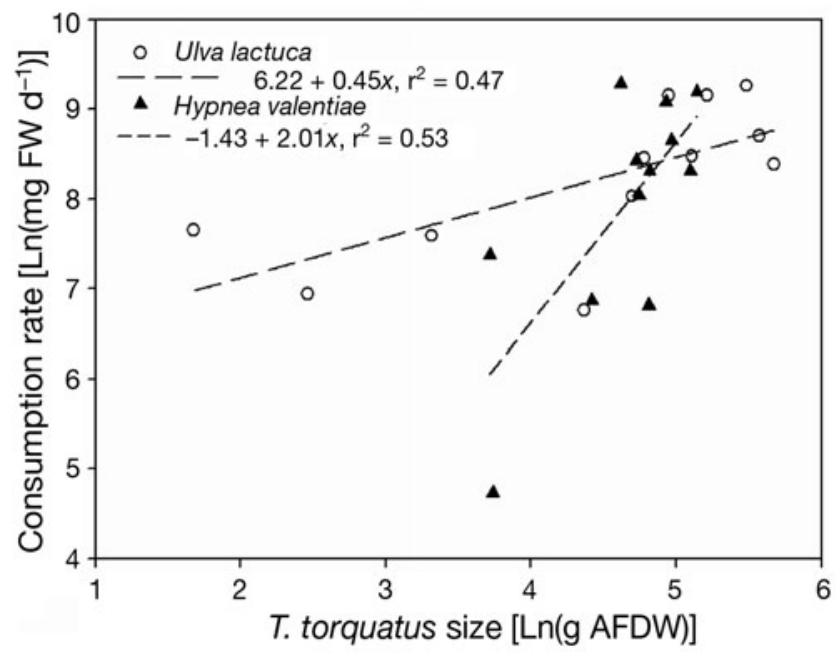

Fig. 5. Turbo torquatus. Consumption rates of Ulva lactuca and Hypnea valentiae fed to single individuals of gastropods of different sizes. Dashed lines are linear regression models fitted to the data points $(n=12, p<0.01)$ 
Table 4. Turbo torquatus. Biometric relationships. WW: wet weight (g); AFDW: ash-free dry weight $(\mathrm{g})$; OD: widest operculum diameter $(\mathrm{mm})$; TSL: total shell length (mm)

\begin{tabular}{|lccc|}
\hline Relationship & $\begin{array}{c}\text { Intercept } \\
( \pm \mathrm{SE})\end{array}$ & $\begin{array}{c}\text { Slope } \\
( \pm \mathrm{SE})\end{array}$ & Regression statistics \\
\hline Ln(WW) to $\ln (\mathrm{AFDW})$ & $-3.26 \pm 0.70$ & $1.35 \pm 0.19$ & $\mathrm{r}^{2}=0.67, \mathrm{n}=28, \mathrm{p}<0.001$ \\
OD to $\ln (\mathrm{AFDW})$ & $-0.69 \pm 0.60$ & $0.14 \pm 0.03$ & $\mathrm{r}^{2}=0.40, \mathrm{n}=28, \mathrm{p}<0.001$ \\
TSL to $\ln ($ AFDW $)$ & $-2.63 \pm 0.58$ & $0.08 \pm 0.01$ & $\mathrm{r}^{2}=0.69, \mathrm{n}=28, \mathrm{p}<0.001$ \\
\hline
\end{tabular}

Overall, the densities found in the present study were similar to values that have been found for several other large turbinids in a range of habitats in different countries (Table 5). Significant differences among reefs within all 4 locations mirror the findings of Vanderklift \& Kendrick (2004) and suggest that reef-specific properties play a role in determining the local abundance of turbinids, although this according to gastropod density and size, and the functional group of the algae.

\section{Abundance and size structure}

Turbinid gastropods were found at all 4 locations. Turbo torquatus accounted for the vast majority of individuals at all locations, including Kalbarri, which is approximately $100 \mathrm{~km}$ north of Port Gregory, the previously published northern limit of the species (Wilson 1993). The latitudes surveyed in the present study did not appear to influence the abundance of turbinids systematically, with one location (Marmion) hosting significantly higher abundances than other locations. The size structure of $T$. torquatus populations did vary with latitude; the 2 southern locations spanned the full range of gastropod sizes recorded, although one location was dominated by large and the other by small individuals. In contrast, both of the northern locations were strongly dominated by one intermediate size class. appears to be less important than broad-scale (100s of kilometres) influences. The large variation among transects within reefs is likely attributable to some combination of the 3-dimensional structure of the reef and the mosaic configuration of the canopy habitatgastropods were commonly seen occupying crevices or under full canopy cover, although these observations must be further substantiated. Nevertheless, most of the variation in abundance was found between locations because Marmion Lagoon had conspicuously higher densities of turbinids than anywhere else.

Ocean currents and upwelling can cause dramatic broad-scale patterns in recruitment and abundance of marine invertebrates (Connolly et al. 2001, Menge et al. 2003). Nevertheless, circulation patterns are unlikely to be the main explanation for the broad-scale patterns in abundance and population size structure of Turbo torquatus along the west coast of Australia, where the warm Leeuwin Current runs from north to south without any substantial upwelling zones or other major discontinuities (Pearce 1991). Biogeographic patterns in abundance and population structure of intertidal gas-

Table 5. Turbo spp. Densities recorded for different species in different habitats

\begin{tabular}{|c|c|c|c|c|c|}
\hline Species & $\begin{array}{l}\text { Density } \\
\text { (ind. } \mathrm{m}^{-2} \text { ) }\end{array}$ & $\begin{array}{l}\text { Size range } \\
\quad(\mathrm{mm})\end{array}$ & Habitat & Location & Source \\
\hline T. torquatus & $0-2.4$ & $9-119$ & $\begin{array}{l}\text { Subtidal limestone and } \\
\text { sandstone reefs, offshore, } \\
\text { wave-exposed reefs, } 10-12 \mathrm{~m}\end{array}$ & West coast, Australia & Present study \\
\hline T. torquatus & $0.2-1.1$ & - & $\begin{array}{l}\text { Subtidal limestone reefs, pre- } \\
\text { dominantly protected, } 5-10 \mathrm{~m}\end{array}$ & West coast, Australia & $\begin{array}{l}\text { Vanderklift \& } \\
\text { Kendrick (2004) }\end{array}$ \\
\hline T. torquatus & $0-0.2$ & - & $\begin{array}{l}\text { Subtidal limestone and } \\
\text { granite reefs, } 3-10 \mathrm{~m}\end{array}$ & South coast, Australia & $\begin{array}{l}\text { Fowler-Walker \& } \\
\text { Connell (2002) }\end{array}$ \\
\hline T. torquatus & 1.1 & $28-74$ & $\begin{array}{l}\text { Subtidal boulder reef, } \\
\text { near-shore, protected, }<5 \mathrm{~m}\end{array}$ & West Island, South Australia & $\begin{array}{l}\text { Clarkson \& } \\
\text { Shepherd (1985) }\end{array}$ \\
\hline T. undulatus & 9.8 & $26-40$ & $\begin{array}{l}\text { Subtidal boulder reef, } \\
\text { near-shore, protected, }<5 \mathrm{~m}\end{array}$ & West Island, South Australia & $\begin{array}{l}\text { Clarkson \& } \\
\text { Shepherd (1985) }\end{array}$ \\
\hline T. smaragdus & $0-21$ & $20-80$ & Subtidal reef, $<10 \mathrm{~m}$ & South Island, New Zealand & $\begin{array}{l}\text { Davidson \& } \\
\text { Chadderton (1994) }\end{array}$ \\
\hline T. sarmaticus & $0.3-1.7$ & $30-100$ & Intertidal boulder reef & $\begin{array}{l}\text { Eastern Cape Province, } \\
\text { South Africa }\end{array}$ & $\begin{array}{l}\text { Foster \& Hodgson } \\
(2000)\end{array}$ \\
\hline T. brunneus & $1-5$ & $30-50$ & $\begin{array}{l}\text { Intertidal sand, mangrove } \\
\text { and coral rubble }\end{array}$ & North Sulawesi, Indonesia & Ompi (1994) \\
\hline
\end{tabular}


tropods have been linked to differences in recruitment dynamics under different ocean temperatures (Zacherl et al. 2003, Gilman 2006, Lima et al. 2006). The latitudes covered in this study are associated with a temperature gradient of 2 to $4^{\circ} \mathrm{C}$ (Fig. 1; Pearce 1991), and systematic variation in ocean temperature could explain some of the patterns in size structure if successful reproduction or recruitment is constrained by high temperatures. T. torquatus is a temperate species that is widely distributed in the cooler waters of the south coast of Australia. Spawning can take place several times a year, including during high summer temperatures (Joll 1980). It therefore seems unlikely that the temperature gradient affects reproduction. Successful recruitment and juvenile survival could, however, be the bottleneck, as demonstrated by Gilman (2006) for the limpet Collisella scabra. The strong dominance of a narrow range of sizes of gastropods, at the 2 northern locations, could be explained if successful recruitment of $T$. torquatus is restricted to infrequently occurring (years apart) occasions of relatively cool conditions (e.g. ENSO-related events) (e.g. Zacherl et al. 2003, Lima et al. 2006). No growth rates are available for $T$. torquatus, but, assuming a growth rate of $12.9 \mathrm{~mm} \mathrm{yr}^{-1}$, the average reported by Foster et al. (1999) for the similar-sized congener $T$. sarmaticus feeding on foliose algae in South Africa suggests that the 40 to $60 \mathrm{~mm}$ individuals dominating populations in Jurien Bay and Kalbarri could be between 3.1 and $4.7 \mathrm{yr}$ old. If so, they would have recruited between 2001 and 2004, which was a period of relatively cool coastal waters on the west coast of Australia (Pearce \& Feng 2007). In contrast, the wide range of sizes of $T$. torquatus encountered at both of the southern locations suggests that $T$. torquatus recruitment occurs regularly here (probably every year). Long-term data on recruitment along the latitudinal gradient, and more detailed studies on the influence of temperature on fecundity and recruitment, are however needed to fully address these speculations.

Ocean climate does not explain the differences in abundance and size structure between the 2 southern locations, Hamelin Bay (a sparsely populated rural area) and Marmion Lagoon (a heavily populated urban area). Regional differences in fishing pressure on Turbo spp. predators (e.g. western blue grouper Achoerodus gouldii) or systematic differences in the quality of available food items could drive the patterns of these 2 locations. Removal of large predatory fish by fishing can strongly reduce predation rates, resulting in considerable effects on abundance and population size structure of invertebrate herbivores (Shears \& Babcock 2002, Hereu et al. 2005). Often, the smaller size classes are targeted by predators, causing size-frequency distributions of prey to be skewed towards larger individuals under low fishing pressure (i.e. in Hamelin Bay). In addition, the high abundance of turbinids, and small $T$. torquatus in particular, in Marmion Lagoon, may reflect increased performance and reproductive potential on a diet of Ulva lactuca and other easily palatable growth forms (Foster et al. 1999) commonly found on humandominated coasts. Tethering experiments comparing predation rates among locations (e.g. Vanderklift et al. 2007) and studies of diet and fecundity (e.g. Foster et al. 1999) could be used to test these hypotheses.

\section{Grazing}

Our assays detected significant grazing of all macroalgae offered to Turbo torquatus, and this demonstrates unambiguously that the species has an ability to consume a wide variety of macroalgae representing a range of functional groups. While these nochoice feeding assays do not indicate in situ feeding patterns, gut content analyses from several Turbo species suggest that consumption of a variety of macroalgae in the field occurs widely within the genus ( $T$. undulatus, $T$. cornutus, T. sarmaticus, $T$. torquatus; Clarkson \& Shepherd 1985, Worthington \& Fairweather 1989, Chan \& Huang 1998, Foster \& Hodgson 1998). Turbo spp., therefore, appear to be an important exception to Steneck \& Watling's (1982) general classification of limitations to archaeogastropod feeding capabilities based on radula structure. Nevertheless, the overall patterns of consumption were consistent with the theory that higher functional groups provide more structural resistance to herbivory.

It is clear that many Turbo species consume macroalgae; however, information on actual consumption rates is required, in conjunction with information on abundance and distribution, to estimate their potential impact (e.g. Sala \& Graham 2002). Consumption rates of $T$. torquatus were size dependant and varied between 30 and $90 \mathrm{mg} \mathrm{FW}$ ind. ${ }^{-1} \mathrm{~d}^{-1}$; these rates scale well with consumption rates for other common herbivorous invertebrates in kelp beds: Aora typica (amphipod), 1 to $3 \mathrm{mg} \mathrm{FW}$ ind. ${ }^{-1} \mathrm{~d}^{-1}$ (Taylor \& Brown 2006); Lacuna vincta (gastropod), up to $42 \mathrm{mg} \mathrm{FW}$ ind. ${ }^{-1} \mathrm{~d}^{-1}$ (Johnson \& Mann 1986); and Holopneustes purpurescens (urchin), $1000 \mathrm{mg} \mathrm{FW} \mathrm{ind.}{ }^{-1} \mathrm{~d}^{-1}$ (Steinberg 1995).

Consumption rates of Turbo torquatus differed between algal food sources, between densities of gastropods and between sizes of gastropods. Other studies of invertebrate herbivores in kelp beds have found similar results. Taylor \& Brown (2006) and Davis et al. (2005) found Ulva lactuca to be the preferred and most readily eaten alga, relative to other common algae, by the amphipod Aora typica and the turbinid gastropod T. undulatus, respectively, and Johnson \& Mann (1986) found a clear pattern of size-dependent consumption 
of the kelp Saccharina by the gastropod L. vincta. These patterns in consumption rates suggest that, in addition to well-established differences among species (Sala \& Graham 2002 and references herein), per capita interaction strengths also vary within a species according to its density, size and the food sources available. This complicates assessments of the relative importance of individual herbivores because, as our surveys have clearly shown, herbivore populations can vary greatly in abundance and size structure across a range of spatial scales, and so do algal assemblages (Wernberg et al. 2003). A more general implication is that processes that change the range of food sources available, the density, or the size structure of herbivores, also change the potential for top-down control. This, in turn, may have consequences for the resilience of the community to perturbations (McCann et al. 1998). A range of human activities represents processes with the potential to have such effects. Eutrophication, for example, commonly shifts the relative abundance of functional groups of algae (Pedersen \& Borum 1997), while fishing (i.e. predator removal) can cause changes to densities and size structures of herbivore populations (Shears \& Babcock 2002, Hereu et al. 2005).

The per capita interaction strength between Turbo torquatus and Ecklonia radiata recruits at a density of 5 ind. aquarium $^{-1}$ can be calculated to be -0.0396 (cf. Sala \& Graham 2002); this is on the same order of magnitude as the highest per capita interaction strengths of -0.0132 to -0.0154 calculated for urchins and large gastropods grazing on microscopic kelp sporophytes in California (Sala \& Graham 2002). The interaction strength between $T$. torquatus and E. radiata is however substantially lower (88\%) than the interaction strength between $T$. torquatus and Ulva lactuca (-0.3311). Based on these interaction strengths it would appear that $T$. torquatus has the potential to have a relatively large influence on reef algae. The extent to which this potential is realised depends on the density of gastropods and the productivity of the algae. E. radiata is the main foundation species on shallow temperate reefs in Australia, and grazing on this species would have the largest implications to the reef community. Reefs at Marmion typically have 12 E. radiata recruits $\mathrm{m}^{-2}$ (Wernberg 2008), and, with an average size of $10 \mathrm{~cm}$ (Kirkman 1984), this corresponds to $36 \mathrm{~g} \mathrm{FW} \mathrm{m}^{-2}$. The average productivity of E. radiata at $10 \mathrm{~m}$ depth has been measured at $0.0167 \mathrm{~g} \mathrm{FW} \mathrm{g}^{-1}$ $\mathrm{FW} \mathrm{d}^{-1}$ (Fairhead \& Cheshire 2004, converted from carbon by assuming a carbon content $=6 \%$ of $\mathrm{FW}_{\mathrm{i}} \mathrm{T}$. Wernberg unpubl. data). The total productivity of recruits therefore amounts to $601 \mathrm{mg} \mathrm{FW} \mathrm{m}^{-2} \mathrm{~d}^{-1}$. If 5 individual $T$. torquatus can eat $150 \mathrm{mg} \mathrm{FW} \mathrm{d}^{-1}$, populations at the maximum densities encountered in the field could consume up to $\sim 11 \%$ of the daily production of kelp recruits at Marmion. This is obviously a very crude calculation, but the relatively low value supports the notion that Turbo spp. likely exert a limited effect on macroscopic reef algae in southern and western Australia (Fowler-Walker \& Connell 2002, Vanderklift \& Kendrick 2004). Nevertheless, a low consumption of total biomass does not necessarily imply low importance, as grazing scars can lead to significant indirect loss of biomass (Johnson \& Mann 1986) and removal of propagules in the grazing process could affect community structure (Malm et al. 1999).

\section{Biometric relationships}

Quantitative knowledge of biomass distribution is critical to evaluate energy flow and community structure, and this is often the ultimate aim of many stock assessments. Several easily obtainable measures of Turbo torquatus size (WW, OD and TSL) were good predictors of AFDW, implying that gastropod biomass can be reliably assessed non-destructively in situ. This is particularly desirable in relation to protected or vulnerable populations such as inside marine protected areas, or at heavily exploited reefs (e.g. Foster \& Hodgson 2000). Furthermore, gastropod shells and opercula are durable even on geological time scales, and they are often found in deposits of geological and prehistoric human origin such as middens (Cann et al. 1991). The biometric relationships can therefore also be used to reconstruct past biomass distributions.

\section{CONCLUSIONS}

Three main insights have resulted from this study: (1) densities of turbinid gastropods on offshore, waveexposed reefs are similar to those that have previously been recorded in other habitats; (2) geographical patterns in abundance and size structure were consistent with patterns produced by processes that encompass broad spatial scales, such as ocean climate, differences in fishing pressure and urban eutrophication; and (3) Turbo torquatus can consume a range of macroalgae, encompassing different thallus morphologies, at rates that suggest it has the potential to exert top-down control of reef algae. Such strong effects are, however, probably limited by low densities of gastropods in situ.

Acknowledgements. This research was funded by the Australian Research Council through a Discovery grant to T.W. (DP0555929). Components of this research were completed by M.W. as part of her Honours degree in Marine Science. We 
are grateful to G. Kendrick and R. Black for constructive criticism and comments at various stages of this work and manuscript. We thank G. Kendrick, K. Cook, K. Waddington, C. Bertolini, F. Tuya and M. Thomsen for assistance in the field, and M. Feng (CSIRO Marine and Atmospheric Research) for updating us on recent ENSO events. This work was covered by permits from the Department of Environment and Conservation (Western Australia), and it complies with institutional, national and international standards for the use of animals in research.

\section{LITERATURE CITED}

Anderson MJ (2005) PERMANOVA: a FORTRAN computer program for permutational multivariate analysis of variance. Department of Statistics, University of Auckland

Ayling AM (1981) The role of biological disturbances in temperate subtidal encrusting communities. Ecology 62: 830-847

Bruton J, Baird D, Coetzee PS (1991) Population structure and yield-per-recruit analysis of the giant periwinkle Turbo sarmaticus in the Cape Francis region, South Africa. S Afr J Mar Sci 11:345-356

Cann JH, Decker PD, Murray-Wallace CV (1991) Coastal aboriginal shell middens and their palaeoenvironmental significance, Robe Range, South Australia. Trans R Soc South Aust 115:161-175

Chan BKK, Huang R (1998) Diet and feeding preference of Turbo cornutus (Gastropoda: Turbinidae) in Hong Kong. In: Morton B (ed) Proceedings of the 10th international marine biological workshop: the marine flora and fauna of Hong Kong and southern China. Hong Kong University Press, p 205-216

Clarke KR, Warwick RM (2001) Change in marine communities - an approach to statistical analysis and interpretation. PRIMER-E, Plymouth

Clarkson PS, Shepherd SA (1985) Distribution and feeding of archaeogastropods in a boulder habitat at West Island, South Australia. J Malacol Soc Aust 7:35-44

Connolly SR, Menge BA, Roughgarden J (2001) A latitudinal gradient in recruitment of intertidal invertebrates in the northeast Pacific Ocean. Ecology 82:1799-1813

Cronin G, Lodge DM, Hay ME, Miller M and others (2002) Crayfish feeding preferences for fresh water macrophytes: the influence of plant structure and chemistry. J Crustac Biol 22:708-718

Davidson RJ, Chadderton WL (1994) Marine reserve site selection along the Abel Tasman National Park coast, New Zealand: consideration of subtidal rocky communities. Aquat Conserv 4:153-167

Davis AR, Benkendorff K, Ward DW (2005) Responses of common SE Australian herbivores to three suspected invasive Caulerpa spp. Mar Biol 146:859-868

Edgar GJ, Barrett NS, Morton AJ, Samson CR (2004) Effects of algal canopy clearance on plant, fish and macroinvertebrate communities on eastern Tasmanian reefs. J Exp Mar Biol Ecol 312:67-87

Fairhead VA, Cheshire AC (2004) Rates of primary productivity and growth in Ecklonia radiata measured at different depths, over an annual cycle, at West Island, South Australia. Mar Biol 145:41-50

Foster GG, Hodgson AN (1998) Consumption and apparent dry matter digestibility of six intertidal macroalgae by Turbo sarmaticus (Mollusca: Vetigastropoda: Turbinidae). Aquaculture 167:211-227

Foster GG, Hodgson AN (2000) Intertidal population struc- ture of the edible mollusc Turbo sarmaticus (Vetigastropoda) at an unexploited and exploited sites along the coast of the eastern Cape Province, South Africa. Afr Zool 35:173-183

Foster GG, Hodgson AN, Balarin M (1999) Effect of diet on growth rate and reproductive fitness of Turbo sarmaticus (Mollusca: Vetigastropoda: Turbinidae). Mar Biol 134: 307-315

Fowler-Walker MJ, Connell SD (2002) Opposing states of subtidal habitat across temperate Australia: consistency and predictability in kelp canopy-benthic associations. Mar Ecol Prog Ser 240:49-56

$>$ Gilman SE (2006) The northern geographic range limit of the intertidal limpet Collisella scabra: a test of performance, recruitment, and temperature hypotheses. Ecography 29: 709-720

Hagen NT (1995) Recurrent destructive grazing of successionally immature kelp forests by green sea urchins in Vestfjorden, northern Norway. Mar Ecol Prog Ser 123: 95-106

Hereu B, Zabala M, Linares C, Sala E (2005) The effects of predator abundance and habitat structural complexity on survival of juvenile sea urchins. Mar Biol 146: 293-299

Hill NA, Blount C, Poore AGB, Worthington D, Steinberg PD (2003) Grazing effects of the sea urchin Centrostephanus rodgersii in two contrasting rocky reef habitats: effects of urchin density and its implications for the fishery. Mar Freshw Res 54:691-700

Jenkins SR, Coleman RA, Della Santina P, Hawkins SJ, Burrows MT, Hartnoll RG (2005) Regional scale differences in the determinism of grazing effects in the rocky intertidal. Mar Ecol Prog Ser 287:77-86

Johnson CR, Mann KH (1986) The importance of plant defense abilities to the structure of subtidal seaweed communities: the kelp Laminaria longicruris survives grazing by the snail Lacuna vincta at high population densities. J Exp Mar Biol Ecol 97:231-268

Joll LM (1980) Reproductive biology of two species of Turbinidae (Mollusca: Gastropoda). Aust J Mar Freshw Res 31: 319-336

Kirkman H (1984) Standing stock and production of Ecklonia radiata (C. Ag.) J. Agardh. J Exp Mar Biol Ecol 76:119-130

> Kraufvelin P, Salovius S, Christie H, Moy FE, Karez R, Pedersen MF (2006) Eutrophication-induced changes in benthic algae affect the behaviour and fitness of the marine amphipod Gammarus locusta. Aquat Bot 84:199-209

> Lima FP, Queiroz N, Ribeiro PA, Hawkins SJ, Santos AM (2006) Recent changes in the distribution of a marine gastropod, Patella rustica Linnaeus, 1758, and their relationship to unusual climatic events. J Biogeogr 33:812-822

Lotze HK, Worm B (2000) Variable and complementary effects of herbivores on different life stages of bloomforming macroalgae. Mar Ecol Prog Ser 200:167-175

> Malm T, Engkvist R, Kautsky L (1999) Grazing effects of two freshwater snails on juvenile Fucus vesiculosus in the Baltic Sea. Mar Ecol Prog Ser 188:63-71

> McCann K, Hastings A, Huxel GA (1998) Weak trophic interactions and the balance of nature. Nature 395:794-798

Menge BA, Lubchenco J, Bracken MES, Chan F and others (2003) Coastal oceanography sets the pace of rocky intertidal community dynamics. Proc Natl Acad Sci USA 100: 12229-12234

Ompi M (1994) The occurrence and size distribution of Turbo spp. in three intertidal areas of north Sulawesi, Indonesia. Spec Publ Phuket Mar Biol Cent 13:143-146

> Paul NA, de Nys R, Steinberg PD (2006) Seaweed-herbivore interactions at a small scale: direct tests of feeding deter- 
rence by filamentous algae. Mar Ecol Prog Ser 323:1-9

Pearce AF (1991) Eastern boundary currents of the southern hemisphere. J R Soc West Aust 74:35-45

Pearce AF, Feng M (2007) Observations of warming on the Western Australian continental shelf. Mar Freshw Res 58: 914-920

Pedersen MF, Borum J (1997) Nutrient control of estuarine macroalgae: growth strategy and the balance between nitrogen requirements and uptake. Mar Ecol Prog Ser 161: 155-163

Sala E, Graham MH (2002) Community-wide distribution of predator-prey interaction strength in kelp forests. Proc Natl Acad Sci USA 99:3678-3683

Shears NT, Babcock RC (2002) Marine reserves demonstrate top-down control of community structure on temperate reefs. Oecologia 132:131-142

Steinberg PD (1995) Interaction between the canopy dwelling echinoid Holopneustes purpurescens and its host kelp Ecklonia radiata. Mar Ecol Prog Ser 127:169-181

Steneck RS, Watling L (1982) Feeding capabilities and limitation of herbivorous molluscs: a functional group approach. Mar Biol 68:299-319

Taylor RB, Brown PJ (2006) Herbivory in the gammarid amphipod Aora typica: relationships between consumption rates, performance and abundance across ten seaweed species. Mar Biol 149:455-463

Vanderklift MA, Kendrick GA (2004) Variation in abundances of herbivorous invertebrates in temperate subtidal rocky reef habitats. Mar Freshw Res 55:93-103

Vanderklift MA, How J, Wernberg T, MacArthur LD, Heck KL Jr, Valentine JF (2007) Proximity to reef influences the density of small predatory fishes while type of seagrass

Editorial responsibility: Otto Kinne, Oldendorf/Luhe, Germany influences intensity of predation on crabs. Mar Ecol Prog Ser 340:235-243

Wernberg T (2008) Spatial variation in population structure of Ecklonia radiata (Laminariales) sporophytes. Aquat Bot (in press)

- Wernberg T, Kendrick GA, Phillips JC (2003) Regional differences in kelp-associated algal assemblages on temperate limestone reefs in south-western Australia. Divers Distrib 9: 427-441

Wernberg T, Vanderklift MA, How J, Lavery PS (2006) Export of detached macroalgae from reefs to adjacent seagrass beds. Oecologia 147:692-701

Wilson BR (1993) Australian marine shells. 1. Prosobranch gastropods. Odyssey Publishing, Kallaroo

Womersley HBS (1984) The marine benthic flora of southern Australia, Part I. South Australian Government Printing Division, Adelaide

Womersley HBS (1987) The marine benthic flora of southern Australia, Part II. South Australian Government Printing Division, Adelaide

Womersley HBS (1994) The marine benthic flora of southern Australia, Part IIIA. Australian Biological Resource Study, Canberra

Worthington DG, Fairweather PG (1989) Shelter and food: interactions between Turbo undulatum (Archaeogastropoda: Turbinidae) and coralline algae on rocky seashores in New South Wales, Australia. J Exp Mar Biol Ecol 129: 61-80

> Zacherl D, Gaines SD, Lonhart SI (2003) The limits to biogeographical distributions: insights from the northward range extension of the marine snail, Kelletia kelletii (Forbes, 1852). J Biogeogr 30:913-924

Submitted: May 10, 2007; Accepted: January 24, 2008

Proofs received from author(s): June 18, 2008 